\title{
Impact of heavy metal contamination on milk and underground water of the New Valley, Egypt
}

\author{
El-Bassiony, Tawfik A. ${ }^{1}$, Amin, Wallaa F. ${ }^{1}$, Ahmed, Ebtsam O. ${ }^{2}$ \\ ${ }^{I}$ Department of Food Hygiene, Faculty of Vet. Med., Assiut University, Egypt \\ ${ }^{2}$ Animal Health Research Institute, The New Valley, Egypt
}

\begin{abstract}
The incidence and levels of heavy metals; lead, cadmium and iron were estimated in water of shallow \& deep wells as well as milk of cows reared on those wells in the New Valley Governorate, Egypt. All the samples were contaminated with such elements. The average levels in water were 0.19, 0.03 and 1.44, while in milk were 0.215, 0.05 and 0.73 for $\mathrm{Pb}, \mathrm{Cd}$ and $\mathrm{Fe}$ respectively. Percentages of $\mathrm{Pb}, \mathrm{Cd}$ and Fe levels exceeding permissible levels in water and milk samples were determined. Also, daily and weekly intakes were estimated and compared to standard intakes. Moreover, comparison of standard $\mathrm{Pb}, \mathrm{Cd}$ and $\mathrm{Fe}$ daily intakes from the consumption of $200 \mathrm{ml}$ milk with the estimated intakes in milk samples was done.
\end{abstract}

Keywords: , Heavy metals, milk, New Valley, wells' water

\section{Introduction}

The New Valley Governorate depends on wells water as the only source of water, due to the desert nature of the governorate and its geographical position which prevented the access of the River Nile water. It is dependent on wells and underground Nubian aquifer of the Western Desert, which is one of the largest aquifers in Egypt. All the agriculture, industrial and domestic use depends on it.

Heavy metals are persistent contaminants in the environment that can cause serious environmental and health hazards. They are released into the environment from natural and man-made activities. Some heavy metals (like $\mathrm{Fe}$ ) are essential to maintain proper metabolic activity in living organisms; others (like $\mathrm{Pb}$ and $\mathrm{Cd}$ ) are non-essential and have no biological role [1,2].However, at high concentrations, they can cause toxicity to living organisms [3]. Industrial and agricultural processes have resulted in an increased concentration of heavy metals in air, water and soil and subsequently, taken by plants or animals and find their ways into food chain [4]. Lead is recognized as a known neurotoxicant with major public health concern which causes both acute and chronic intoxication [5]. The toxicity may show in the form of anemia, abdominal colic, liver dysfunction, renal damage, peripheral neuropathy in adults, CNS disorders in the form of permanent brain damage in children and in case of extreme lead poisoning, convulsion followed by coma and death, might occur. Moreover, lead has a biological half life of about 27 years in human bones [6]. Cadmium intoxication in human results in renal damage and dystrophic changes with hypercalcuria, glucosuria, proteinuria and aminoaciduria with hypertension [7], and itai itai disease which is characterized by severe pain, soft bones and death may occur as a result of renal failure [8]. The effect of iron and lead to man could lead to delays in physical and mental development and slight deficit in attention span and learning abilities in infants and children; Kidney problems and high blood pressure in adults. Iron causes skin or tooth discoloration or aesthetic effect such as taste, odor, or color in drinking water which may also lead to nausea, vomiting, diarrhea, as well as blood clotting and may threatens life [9].There have been some complaints about water in the New Valley, and since dairy animals drink from such water, it was necessary to examine water and milk of cows that drink such water. Changes of the water color, kidney problems and nervous manifestations [10] have been observed. So, we aimed to estimate the presence of lead, cadmium and iron in water and milk samples.

The present study aimed to:

1-Estimate the levels of $\mathrm{Pb}, \mathrm{Cd}$ and $\mathrm{Fe}$ in the water of shallow \& deep wells as well as in the milk of cows reared on these wells.

2-Find the correlation between the levels of these heavy metals in water and milk samples.

3- Estimate the percentage of samples exceeding MPL of the examined elements.

4- Estimate daily, weekly intakes and percentages of milk samples exceeding the tolerable daily and weekly intakes.

\section{Materials And Methods}

A total of 50 underground wells water samples were collected from 10 wells at different depth from Mout- El-Dakhla city, New Valley governorate, Egypt. Five deep wells at depth 400-1000m and 5 shallow wells at depth $80-200 \mathrm{~m},\left(5\right.$ samples each). All samples were collected in dry glass bottles and preserved at $4^{\circ} \mathrm{C}$, then transported to the laboratory for estimation of $\mathrm{Pb}, \mathrm{Cd}$ and $\mathrm{Fe}$ concentrations. 
A total of 100 milk samples were collected from cows rearing on the previously mentioned wells and drink from them. All samples were taken in clean and dry glass stoppered tubes and transported under refrigerated condition to the laboratory for estimation of $\mathrm{Pb}, \mathrm{Cd}$ and $\mathrm{Fe}$ concentrations.

\section{b- Analysis of samples:}

The digestion of samples was done as described by [11], while, the metal analysis of the samples was carried out in the Department of Biochemical, Deficiency Disease and Toxicology, Animal Health Research Institute, Dokki, Giza, Egypt. All samples in addition to the blank were analyzed for detection and/or measurement of $\mathrm{Pb}, \mathrm{Cd}$ and $\mathrm{Fe}$ using UNICAM 969 Atomic Absorption Spectrophotometer. The concentration of $\mathrm{Pb}, \mathrm{Cd}$ and $\mathrm{Fe}$ in the examined samples was calculated according to [12]: The content of these heavy metals were expressed as $\mathrm{mg} / \mathrm{kg}$ of the sample based on the weight. The concentration of absorbance values of metals in the blank samples were also calculated and subtracted from each analyzed sample to exclude any traces of metal that might be present in the used acid for digestion.

\section{Results}

Table 1: Incidence and levels of $\mathrm{Pb}, \mathrm{Cd}$ and $\mathrm{Fe}$ in water samples of shallow and deep wells (ppm):

\begin{tabular}{|r|r|r|r|r|r|r|}
\hline \multirow{2}{*}{ Well } & \multirow{2}{*}{ Element } & \multicolumn{2}{|c|}{ Positive samples } & \multirow{2}{*}{ Min. } & \multirow{2}{*}{ Max. } & \multirow{2}{*}{ Average } \\
\cline { 3 - 7 } & & No./25 & $\%$ & & & \\
\hline \multirow{3}{*}{ Shallow } & $\mathrm{Pb}$. & 25 & 100 & 0.0001 & 0.4 & 0.18 \\
\cline { 2 - 7 } & $\mathrm{Cd}$. & 25 & 100 & 0.01 & 0.12 & 0.05 \\
\cline { 2 - 7 } Deep & $\mathrm{Fe}$. & 25 & 100 & 0.01 & 8.8 & 2.18 \\
\hline & $\mathrm{Pb}$. & 25 & 100 & 0.002 & 0.7 & 0.19 \\
\cline { 2 - 7 } & $\mathrm{Cd}$. & 25 & 100 & 0.0001 & 0.06 & 0.01 \\
\cline { 2 - 7 } & $\mathrm{Fe}$. & 25 & 100 & 0.01 & 3.3 & 0.7 \\
\hline
\end{tabular}

Table 2: Incidence and levels of $\mathrm{Pb}, \mathrm{Cd}$ and $\mathrm{Fe}$ in milk samples of cows reared on shallow and deep wells (ppm):

\begin{tabular}{|r|r|r|r|r|r|r|}
\hline \multirow{2}{*}{ Well } & \multirow{2}{*}{ Element } & \multicolumn{2}{|c|}{ Positive samples } & \multirow{2}{*}{ Min. } & \multirow{2}{*}{ Max. } & \multirow{2}{*}{ Average } \\
\cline { 3 - 7 } & & No. & $\%$ & & & \\
\hline \multirow{3}{*}{ Shallow } & $\mathrm{Pb}$. & 50 & 100 & 0.02 & 0.8 & 0.27 \\
\cline { 2 - 7 } & $\mathrm{Cd}$. & 50 & 100 & 0.0001 & 0.2 & 0.07 \\
\cline { 2 - 7 } Deep & $\mathrm{Fe}$. & 50 & 100 & 0.002 & 5.8 & 0.93 \\
\hline & $\mathrm{Pb}$. & 50 & 100 & 0.01 & 0.7 & 0.16 \\
\cline { 2 - 7 } & $\mathrm{Cd}$. & 50 & 100 & 0.0002 & 0.5 & 0.03 \\
\hline & $\mathrm{Fe}$. & 50 & 100 & 0.002 & 5.7 & 0.53 \\
\hline
\end{tabular}

Table 3: Correlation between the average levels of $\mathrm{Pb}, \mathrm{Cd}$ and $\mathrm{Fe}$ in water and milk samples (ppm):

\begin{tabular}{|r|r|r|r|r|r|}
\hline \multirow{3}{*}{ Well } & \multirow{3}{*}{ Element } & \multicolumn{2}{|c|}{ Water } & \multicolumn{2}{|c|}{ Milk } \\
\cline { 3 - 6 } & & $\begin{array}{r}\text { Incidence } \\
\%\end{array}$ & Average & $\begin{array}{r}\text { Incidence } \\
\%\end{array}$ & Average \\
\hline \multirow{3}{*}{ deep } & $\mathrm{Pb}$. & 100 & 0.18 & 100 & $0.27^{*}$ \\
\cline { 2 - 6 } & $\mathrm{Cd}$. & 100 & 0.05 & 100 & $0.07^{*}$ \\
\cline { 2 - 6 } & $\mathrm{Fe}$. & 100 & 2.18 & 100 & $0.93^{*}$ \\
\cline { 2 - 6 } & $\mathrm{Pb}$. & 100 & 0.19 & 100 & $0.16^{*}$ \\
\cline { 2 - 6 } Total & $\mathrm{Cd}$. & 100 & 0.01 & 100 & $0.03^{*}$ \\
\hline & $\mathrm{Fe}$. & 100 & 0.7 & 100 & $0.53^{*}$ \\
\cline { 2 - 6 } & $\mathrm{Pb}$. & 100 & 0.19 & 100 & $0.215^{*}$ \\
\cline { 2 - 6 } & $\mathrm{Cd}$. & 100 & 0.03 & 100 & $0.05^{*}$ \\
\hline
\end{tabular}

* Significant correlation between the corresponding values at $\mathrm{P}<0.05$

Figure 1: Percentages of $\mathrm{Pb}, \mathrm{Cd}$ and Fe levels above MPL in water samples of shallow wells

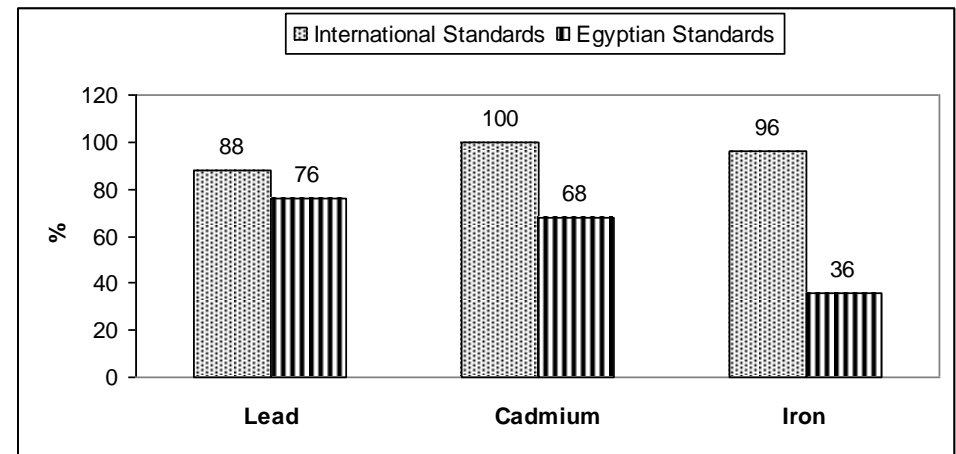


International standards: $\mathrm{WHO}$ (2006), $\mathrm{Pb} 0.01, \mathrm{Cd} 0.003, \mathrm{Fe} 0.05 \mathrm{mg} / \mathrm{kg}$

Egyptian standards: ECS (1994), Pb 0.05, Cd 0.01, Fe $1 \mathrm{mg} / \mathrm{kg}$

Figure 2: Percentages of $\mathrm{Pb}, \mathrm{Cd}$ and $\mathrm{Fe}$ levels above MPL milk samples of cows reared on shallow wells

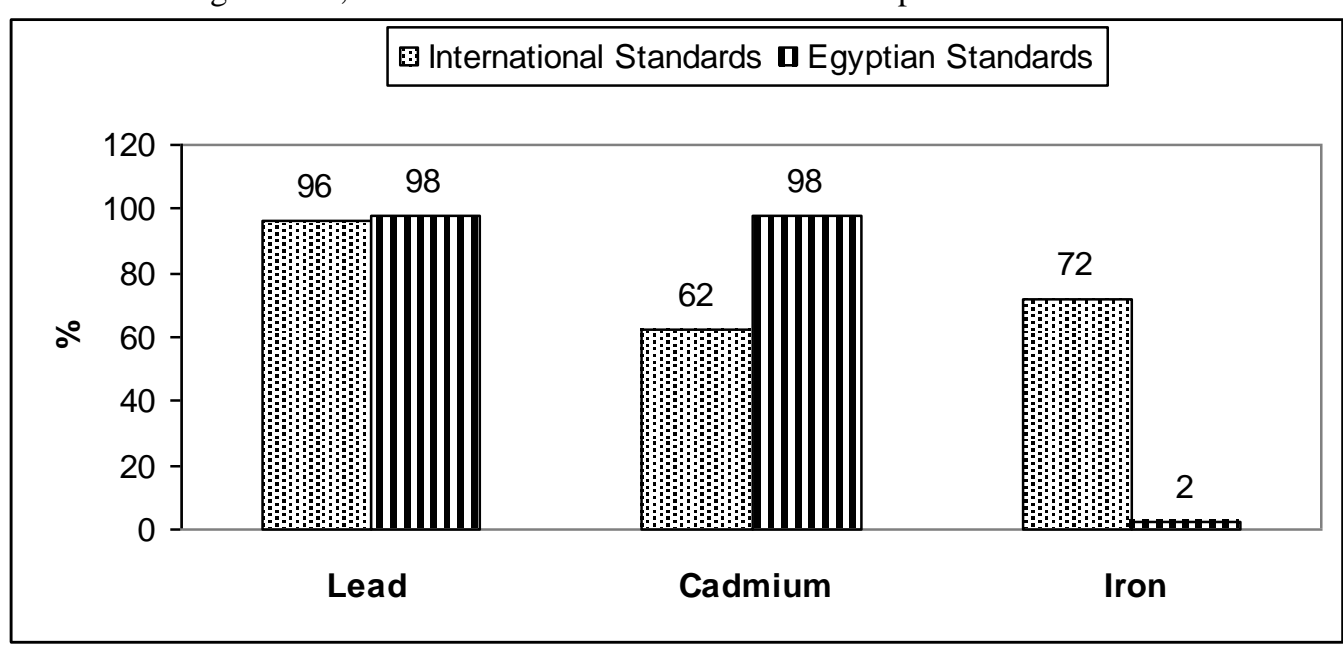

International standards: IDF (1979), $\mathrm{Pb} 0.049, \mathrm{Cd} 0.026, \mathrm{Fe} 0.37 \mathrm{mg} / \mathrm{kg}$

Egyptian standards: EOSQC (1993), Pb 0.02, Cd 0.002, Fe 5 mg/kg

Figure 3: Percentages of $\mathrm{Pb}, \mathrm{Cd}$ and $\mathrm{Fe}$ levels above MPL in water samples of deep wells.

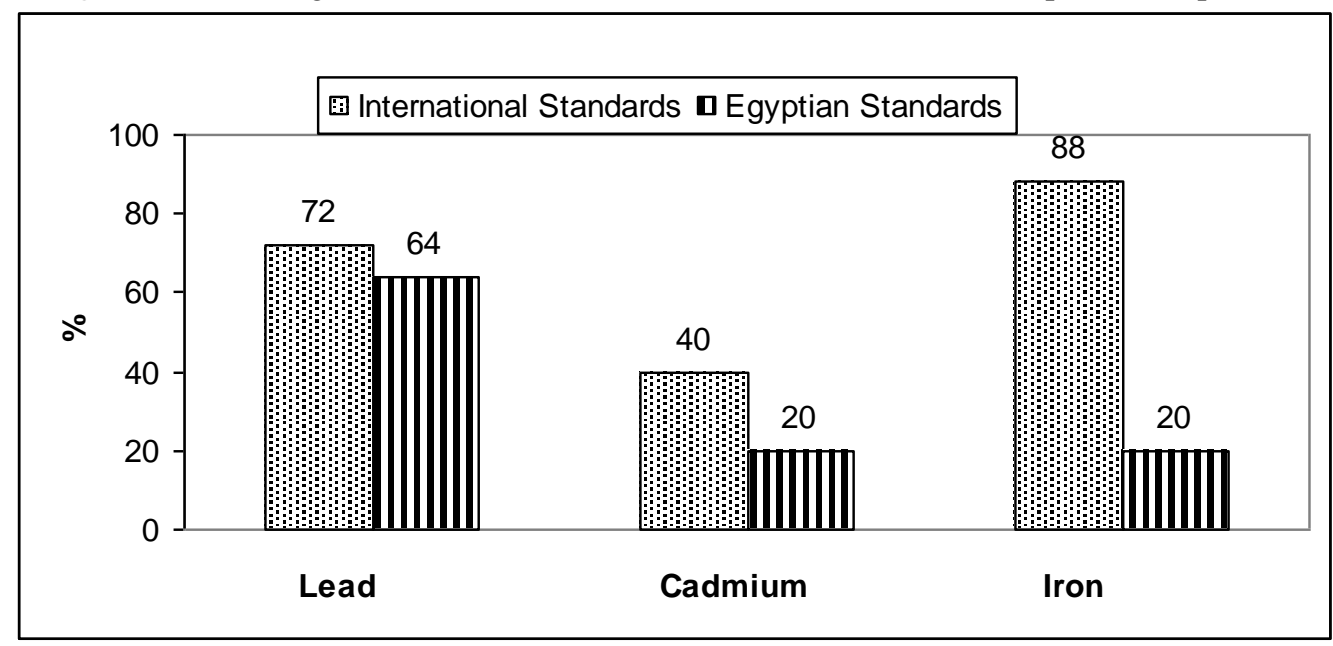

Figure 4: Percentages of $\mathrm{Pb}, \mathrm{Cd}$ and Fe levels above MPL in milk samples of cows reared on deep wells

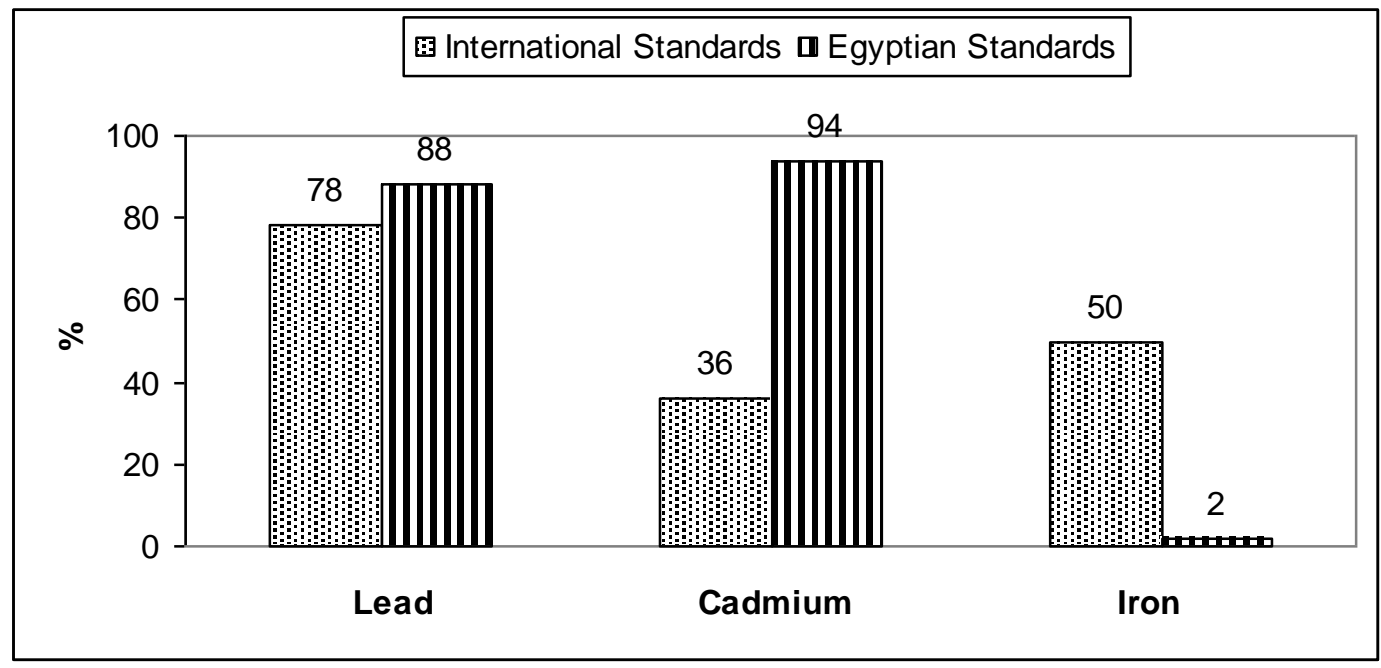


Figure 5: Percentages of $\mathrm{Pb}, \mathrm{Cd}$ and Fe levels above MPL in all milk samples of cows reared on under ground water.

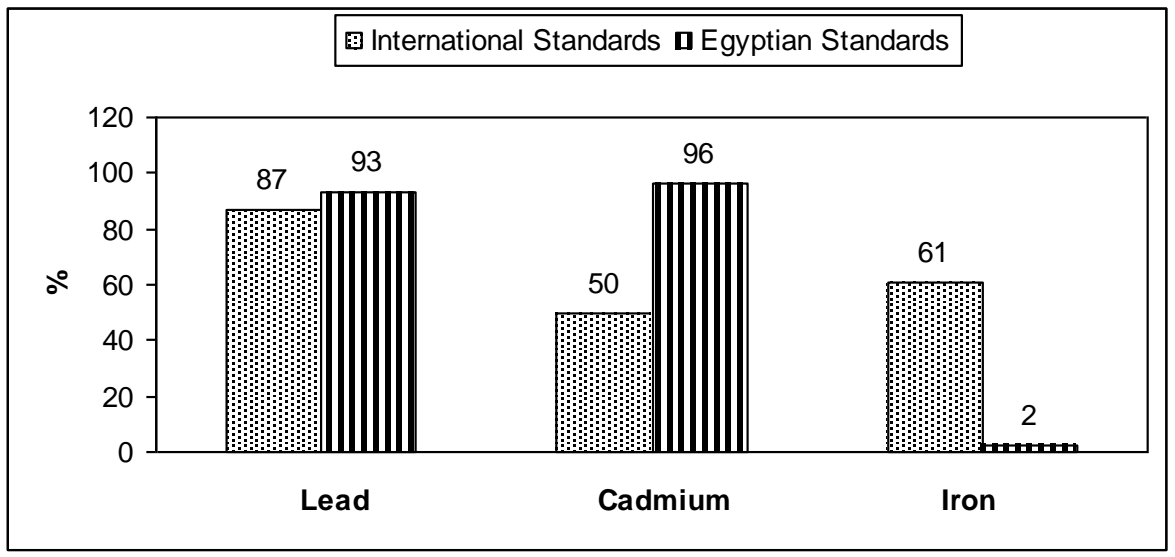

Table 4: Comparison of standard $\mathrm{Pb}, \mathrm{Cd}$ and $\mathrm{Fe}$ intakes with that estimated in milk samples:

\begin{tabular}{|c|c|c|c|c|c|c|c|c|c|c|}
\hline & \multirow{3}{*}{ Well } & \multirow{3}{*}{ Element } & \multicolumn{4}{|r|}{ DI } & \multicolumn{4}{|r|}{ WI } \\
\hline & & & \multirow{2}{*}{ ADI } & \multirow{2}{*}{ EDI } & \multicolumn{2}{|c|}{ Samples above ADI } & \multirow{2}{*}{ PTWI } & \multirow{2}{*}{ EWI } & \multicolumn{2}{|c|}{ Samples above AWI } \\
\hline & & & & & No. & $\%$ & & & No. & $\%$ \\
\hline & \multirow{3}{*}{ Shallow } & Lead & 0.0036 & 0.558 & 50 & 100 & 0.025 & 3.905 & 50 & 100 \\
\hline & & Cadmium & 0.001 & 0.144 & 49 & 98 & 0.007 & 1.012 & 49 & 98 \\
\hline & & Iron & 0.8 & 1.922 & 32 & 64 & 5.6 & 13.454 & 32 & 64 \\
\hline & \multirow{3}{*}{ Deep } & Lead & 0.0036 & 0.330 & 50 & 100 & 0.025 & 2.31 & 50 & 100 \\
\hline & & Cadmium & 0.001 & 0.062 & 49 & 98 & 0.007 & 0.434 & 49 & 98 \\
\hline & & Iron & 0.8 & 1.095 & 18 & 36 & 5.6 & 7.66 & 18 & 36 \\
\hline & \multirow{3}{*}{ Total } & Lead & 0.0036 & 0.444 & 100 & 100 & 0.025 & 3.108 & 100 & 100 \\
\hline & & Cadmium & 0.001 & 0.1033 & 98 & 98 & 0.007 & 0.723 & 98 & 98 \\
\hline & & Iron & 0.8 & 1.5086 & 50 & 50 & 5.6 & 10.560 & 50 & 50 \\
\hline & \\
\hline & \multicolumn{10}{|c|}{$\begin{array}{l}=\text { Daily intake } \\
=\text { Weekly intake }\end{array}$} \\
\hline PTW & \multicolumn{10}{|c|}{ I $=$ Provisional tolerable weekly intake } \\
\hline EWI & \multicolumn{10}{|c|}{$=$ Estimated weekly intake } \\
\hline ADI & \multicolumn{10}{|c|}{$=$ Acceptable daily intake } \\
\hline EDI & \multicolumn{10}{|c|}{$=$ Estimated daily intake } \\
\hline
\end{tabular}

Table 5: Comparison of standard $\mathrm{Pb}, \mathrm{Cd}$ and $\mathrm{Fe}$ daily intakes from consumption of $200 \mathrm{ml}$ milk with the estimated in milk samples:

\begin{tabular}{|r|r|r|r|r|}
\hline Elements & Average value & \multicolumn{3}{|c|}{ DI from consumption of $200 \mathrm{ml}$ milk } \\
\cline { 3 - 5 } & & ADI & EDI & $\%$ \\
\hline $\mathrm{Pb}$ & 0.215 & 0.0036 & 0.043 & 1194 \\
\hline $\mathrm{Cd}$ & 0.05 & 0.001 & 0.01 & 1000 \\
\hline $\mathrm{Fe}$ & 0.73 & 0.8 & 0.146 & 18.25 \\
\hline
\end{tabular}

\section{Discussion}

Incidence and levels of $\mathrm{Pb}, \mathrm{Cd}$ and $\mathrm{Fe}$ in water samples of shallow and deep wells (ppm): The examined water samples of all examined wells were contaminated with $\mathrm{Pb}, \mathrm{Cd}$ and $\mathrm{Fe}$. $\mathrm{As}$ for $\mathrm{Pb}$ in water of shallow wells, the maximum level was $0.4 \mathrm{ppm}$, minimum level was 0.0001 and average value was $0.18 \mathrm{ppm}$, while its levels in water of deep wells were $0.7 \mathrm{ppm}, 0.002 \mathrm{ppm}$ and $0.19 \mathrm{ppm}$ for the maximum, minimum and average levels respectively. Similar results were obtained by $[13,14]$. Lower levels were estimated by $[15,16$, 17] while high levels of $\mathrm{Pb}$ were estimated by $[18,19]$. As the quality of the ground water sources are affected by the characteristics of the media through which the water passes on its way to the ground water zone of saturation [20]. The occurrence of lead and other metals in the water of these areas may be of natural origin (e.g. eroded minerals within sediments, leaching of ore deposits and volcanism extruded products) [21]. The possible sources of $\mathrm{Pb}$ are combustion of old lead pipe line from which water is supplied, idol immersion activities, the use of lead arsenate as pesticide [22].

The average value of $\mathrm{Cd}$ in water of shallow wells was $0.05 \mathrm{ppm}$ ranged from 0.01 to $0.12 \mathrm{ppm}$, while its levels in water of deep wells were $0.06 \mathrm{ppm}, 0.0001 \mathrm{ppm}$ and $0.01 \mathrm{ppm}$ for the maximum, minimum and average levels respectively. Nearly similar results were reported by [13, 15, 16, 23], while [14, 19] reported higher levels. 
The source of cadmium in the water samples may be due to improper disposal of waste sewage and solid wastes material containing toxic chemicals near the wells [24]. The average value of $\mathrm{Fe}$ in water of shallow wells was $2.18 \mathrm{ppm}$ ranged from $0.01 \mathrm{ppm}$ and $8.8 \mathrm{ppm}$. These results were similar to that reported by [22], while lower results were obtained by $[14,17,19]$. While its levels in water of deep wells ranged from 0.01 to $3.3 \mathrm{ppm}$ with an average of $0.7 \mathrm{ppm}$. Similar results were obtained by [14, 19, 22]. Iron is the most commonly available metal on earth [25], the level of iron could be the result of clay deposits in the area [26]. Also the presence of iron is responsible for the brownish red colour of the water when allowed to stay for some minutes [27], high iron in drinking water may reduce the palatability and therefore amount and rate of water intake [28].

Excess iron (greater than $0.3 \mathrm{ppm}$ ) in drinking water is much more absorbable and available than iron from feedstuffs, and thus present a greater risk for causing iron toxicity, consequences of iron toxicity and heightened oxidative stress that are magnified in transition and fresh cows include: compromised immune function, increased fresh cow mastitis and metritis, greater incidence of retained fetal membranes as well as diarrhea, sub-normal feed intake, decreased growth, and impaired milk yield [29]. The prolonged consumption of drinking water with high concentration of iron may lead to liver disease called as heamosidrosis [30].

Incidence and levels of $\mathrm{Pb}, \mathrm{Cd}$ and $\mathrm{Fe}$ in milk samples of cows reared on shallow and deep wells (ppm): All milk samples of cows reared on shallow and deep wells were contaminated with $\mathrm{Pb}, \mathrm{Cd} \& \mathrm{Fe}$.

In milk of cows reared on shallow wells, the maximum level of $\mathrm{Pb}$ was $0.8 \mathrm{ppm}$, minimum level of 0.02 $\mathrm{ppm}$ and average value of $0.27 \mathrm{ppm}$. Also, Cd was detected in an average of $0.07 \mathrm{ppm}$, ranged from 0.0001 to $0.2 \mathrm{ppm}$. Moreover, Fe maximum level was $5.8 \mathrm{ppm}$, minimum level $0.002 \mathrm{ppm}$ and average value of $0.93 \mathrm{ppm}$. In milk of cows reared on deep wells, the maximum level of $\mathrm{Pb}$ was $0.7 \mathrm{ppm}$, minimum level $0.01 \mathrm{ppm}$ and average value $0.16 \mathrm{ppm}$. The source of lead in milk samples is closely related to the contamination of water with lead and also the contamination of soil and fodder which also could be affected with the contaminated water. As foodstuffs grown on agricultural soil or irrigated with impure water accumulate metal contents and are a big source of heavy metals exposure to the animals and humans [31]. One of the most important sources of lead contamination in milk is water, especially in more contaminated areas [32]. A linear dose-related excretion of lead from plasma to milk was found in mice after intravenous injections of lead. However, $24 \mathrm{hrs}$ after administration, lead concentration in milk was found to be higher than that in blood [33], so milk is a very important source for human exposure to lead.

In addition, $C d$ was detected in an average of $0.03 \mathrm{ppm}$, ranged from 0.0002 to $0.5 \mathrm{ppm}$. Milk and dairy products usually contain very low concentration of $\mathrm{Cd}$ except when dairy animals consume contaminated feeds and water [34]. Cadmium source may be attributed to its presence in the underground water used for drinking of cows and also may be due to using of fertilizers or pesticides [35]. While, minimum, maximum and average values of Fe were $0.002 \mathrm{ppm}, 5.7 \mathrm{ppm}$, and $0.53 \mathrm{ppm}$. High levels of iron may be attributed to high contamination of water and feed by such pollutants [36]. Excess iron represents a problem in dairy technology because of its catalytic effect on oxidation of lipids with development of unpleasant smell, bounding preferably proteins and lipoprotein membrane of fatty globule [37].

The obtained results indicate that there is a significant relationship between $\mathrm{Pb}, \mathrm{Cd}$ and $\mathrm{Fe}$ in water samples of shallow and deep wells and milk samples of cows reared on those wells at $p<0.05$, this indicates that dairy animals are exposed to high quantities of toxic metals through water. It is obvious that the average values of $\mathrm{Pb}, \mathrm{Cd}$ and $\mathrm{Fe}$ in milk samples of cows reared on shallow wells were higher than that of cows' milk reared on deep wells, which is explained by the exposure of shallow wells water to pollution of the environment more than deep wells.

Data revealed that the average value of $\mathrm{Pb}, \mathrm{Cd}$ and $\mathrm{Fe}$ in all water samples collected from El-Dakhla City, New Valley Governorate, were $0.19,0.03$ and $1.44 \mathrm{ppm}$, respectively, while the average values of $\mathrm{Pb}, \mathrm{Cd}$ and $\mathrm{Fe}$ in milk samples collected from cows reared on the same area were $0.215,0.05$ and $0.73 \mathrm{ppm}$, respectively. These results show that there is a clear relationship between the presence of these metals in the underground water and their presence in milk samples.

Percentages of levels above MPL in water samples of the under ground water:

It's evident from Fig. $1 \& 3$ that, $88 \%, 100 \%$ and $96 \%$ for $\mathrm{Pb}, \mathrm{Cd}$ and $\mathrm{Fe}$ of the examined water samples of shallow wells were above MPLs mentioned by [38,39], while $76 \%, 68 \%$ and $36 \%$ were above that stated by [40]. Also, $72 \%, 40 \%$ and $88 \%$ of the examined water samples of deep wells were above MPLs stated by [38,39], while $64 \%, 20 \%$ and $20 \%$ were above that reported by [40].

Percentages of levels above MPL in milk samples of cows reared on under ground water: It's obvious from Fig. $2 \& 4$ that, $96 \%, 62 \%$ and $72 \%$ for $\mathrm{Pb}, \mathrm{Cd}$ and $\mathrm{Fe}$ were above MPLs mentioned by [41], while, 98\%, $98 \%$ and $2 \%$ for $\mathrm{Pb}, \mathrm{Cd}$ and $\mathrm{Fe}$ in the examined milk samples of cows reared on shallow wells were above MPLs stated by [42]. While, in the examined milk samples of cows reared on deep wells, $78 \%, 36 \%$ and $50 \%$ for $\mathrm{Pb}, \mathrm{Cd}$ and $\mathrm{Fe}$ were above MPLs mentioned by [41] while $88 \%, 94 \%$ and $2 \%$ for $\mathrm{Pb}, \mathrm{Cd}$ and $\mathrm{Fe}$ were above MPLs recommended by [42]. It's clear that the percentage of samples above MPL of water from shallow wells and milk of cows reared on them are higher than that of deep wells. Moreover, the percentage of $\mathrm{Pb}, \mathrm{Cd}$ and $\mathrm{Fe}$ 
in all examined milk samples above MPL stated by [41] were 87, 50 and 61 respectively, while that above MPL stated by [42] were 93, 96 and 2, respectively (Fig. 5).

Comparison of standard $\mathrm{Pb}, \mathrm{Cd}$ and $\mathrm{Fe}$ intakes with that estimated in milk samples: The EDI and EWI were compared to the ADI and PTWI stated by [43]. In milk of cows reared on shallow wells, the EDI of lead was $0.558 \mathrm{mg} / \mathrm{kg}$ b.w., while EWI was $3.906 \mathrm{mg} / \mathrm{kg} \mathrm{b.w}$. and $100 \%$ of samples were above ADI and PTWI. Food is considered the principal route of lead exposure for people. Adult absorb 5-15\% of the ingested lead, while children absorb 30-40\%. Dietary deficiencies of calcium and iron enhance the absorption of lead [44]. The EDI of cadmium was $0.144 \mathrm{mg} / \mathrm{kg}$ b.w., while the EWI was $1.012 \mathrm{mg} / \mathrm{kg} \mathrm{b.w}$. and $98 \%$ of samples were above ADI and PTWI. Additionally, the EDI of iron was $1.922 \mathrm{mg} / \mathrm{kg}$ b.w., while the EWI was $13.454 \mathrm{mg} / \mathrm{kg}$ b.w. and $64 \%$ of samples were above ADI and PTWI (Table 4).

While, in milk of cows reared on deep wells, the EDI of lead was $0.330 \mathrm{mg} / \mathrm{kg} \mathrm{b} . \mathrm{w}$. and the estimated weekly intake (EWI) was $2.31 \mathrm{mg} / \mathrm{kg}$ b.w. The obtained results were above the ADI and PTWI. Likewise, the EDI of cadmium was $0.062 \mathrm{mg} / \mathrm{kg}$ b.w., while the EWI was $0.434 \mathrm{mg} / \mathrm{kg} \mathrm{b} . w$. and $98 \%$ of samples were above ADI and PTWI. Also, the EDI of iron was $1.095 \mathrm{mg} / \mathrm{kg}$ b.w., while the EWI was $7.66 \mathrm{mg} / \mathrm{kg} \mathrm{b}$.w. and $36 \%$ of samples were above ADI and PTWI. As for all milk samples of cows reared on the underground water, the EDI of lead was $0.444 \mathrm{mg} / \mathrm{kg}$ b.w., while the EWI was $3.108 \mathrm{mg} / \mathrm{kg}$ b.w. and all milk samples were above ADI and PTWI. Also, the EDI of cadmium was $0.1033 \mathrm{mg} / \mathrm{kg}$ b.w., while the EWI was $0.723 \mathrm{mg} / \mathrm{kg} \mathrm{b}$.w. and $98 \%$ of samples were above ADI and PTWI. Moreover, the EDI of iron was $1.5086 \mathrm{mg} / \mathrm{kg}$ b.w., while EWI was 10.560 $\mathrm{mg} / \mathrm{kg}$ b.w. and $50 \%$ of samples were above ADI and PTWI. The obtained results are lower than that estimated by [45].

Comparison of daily intakes from consumption of $200 \mathrm{ml}$ milk with the estimated in all milk samples: The daily intake of measured elements was estimated on the assumption of drinking a cup of $200 \mathrm{ml}$ of milk daily. The results revealed that the estimated daily intake of $\mathrm{Pb}, \mathrm{Cd}$ and $\mathrm{Fe}$ from consumption of $200 \mathrm{ml}$ milk per day were $0.043,0.01$ and $0.146 \mathrm{ppm}$ and this contribute about 1194,1000 and $18.25 \%$ respectively of the ADI (Table 5). Lower results were reported by [46].

\section{Conclusion}

It could be concluded that contaminated water is an important source of $\mathrm{Pb}, \mathrm{Cd}$ and $\mathrm{Fe}$ for animal and likely milk. Also, there is a significant relationship between the levels of $\mathrm{Pb}, \mathrm{Cd}$ and $\mathrm{Fe}$ in the wells' water and their levels in milk samples of cows reared on those wells. Milk samples of cows reared on deep wells were less contaminated than those reared on shallow wells, which indicated that the shallow wells were affected by pollution more than the deep wells. Likewise, high levels of $\mathrm{Pb}, \mathrm{Cd}$ and $\mathrm{Fe}$ in milk samples of cows reared on shallow and deep wells were above MPL mentioned by IDF and EOSQC.

\section{References}

[1]. Ayar, A., Sert, D., Akin, N. (2009). The trace metal levels in milk and dairy products consumed in middle Anatolia-Turkey. Environ. Monitor Assess 152: 1-12.

[2]. Qin, L., Wang, X., Li, W., Tong, X., Tong, W. (2009). Minerals and heavy metals in cow's milk in China and Japan. Journal of Health Science 55: 300-305

[3]. Li, Y., McCrory, D.F., Powel, J.M., Saam, H., Jackson-Smith, D. (2005). A survey of selected heavy metal concentrations in Wisconsin Dairy Feeds. J. Dairy Science 88: 2911-2922.

[4]. Ahmad, W.M.S. (2002). Studies on heavy metal pollution in poultry farms in relation to production performance. Ph.D. thesis, Zagazig University, Egypt.

[5]. Gossel, T.A., Bricker, J.D. (1990). Metals. In: Principles of Clinical Toxicology. 2nd Ed., Raven Press, New York, pp. 162-192.

[6]. Shibamoto, T., Bjeldanes, L.E. (1993). Introduction to food toxicology. Academic Press Inc. Harcourt Brace Company. New York, Food Science \& Technology International Series.

[7]. Gracey, J., Collins, D. (1992). Meat Hygiene. 9th Ed., ELBS with Baillier Tindell, London, U.K., Chap. 10, pp. 205-221.

[8]. Peter, O.N. (1993). Environmental chemistry. 2nd Ed. Champan and Hall Press, New York pp. 203-221.

[9]. Laniyan, T.N., Phillips, O.O.K., Elesha, L. (2011). Hazards of Heavy Metal Contamination on the Ground-Water around a Municipal Dumpsite in Lagos, South-Western Nigeria," International Journal of Engineering \& Technology 11(1): 61-69.

[10]. Farghaly, W.M.A., El-Tallawy, H.N.A., Shehata, G.A., Rageh, T.A., Abdel Hakeem, N., Abo- Elfetoh, N.A. (2011). Populationbased study of acquired cerebellar ataxia in Al-Kharga district, New Valley, Egypt. Neuropsychiatr. Dis. Treat. 7: $183-187$.

[11]. Kolmer, J.A, Spauddling, E.H., Robinson, H.W. (1951). Approved Laboratory Techniques. New York, Appletion Century Crafts, pp: 1090:1091.

[12]. Horwitz, W. (2000). Official Methods of Analysis of AOAC International 17th Ed., Vol. (1). AOAC International, Suite 500, 481 Nourth Frederick Avenue, Gaithersburg, Maryland 20877-2417 USA.

[13]. Fahim, F.A., Badawy, M.M., El-Ries, M.A, El-Shahed, A.S., Abdel-Aleem, M.K. (1995). Evaluation of the ground water at sewage disposal and heavily population area in Egypt. German-Egyptian Conference, Ismailia: 74-92

[14]. Kamel, N. H., Sayyah A. M., Abdel-aal, A. A (2011). Ground Water in Certain Sites in Egypt and Its Treatments Using a New Modified Ion Exchange Resin-Characterization of Water and Modified Ion Exchange. Pak. J. Nutrition 2(2): 98-101.

[15]. Nassef, M., Hannigan, R., EL Sayed, K.A., El-Tahawy, M.S. (2006). Determination of some heavy metals in the environment of Sadat industrial city. Proceeding of the 2nd Environmental Physics Conference, Cairo University, Egypt, pp. 145-152.

[16]. Alabdula'aly, A.I.; Al Zarah, A.I., Khan, M.A. (2011). Assessment of Trace Metals in Groundwater Sources Used for Drinking Purposes in Riyadh Region. Intl. J. Water Resources \& Arid Environ. 1(1): 05-09. 
[17]. Alshikh A. (2011). Analysis of Heavy Metals and Organic Pollutants of Ground Water Samples of South Saudi. Life Science J. 8(4): 438-441.

[18]. Tork, I.Y. (1994). Cadmium and lead in water, milk and animal feeds. Alex.J. Vet Sci. 10(2): 27-32.

[19]. [19]. Sonousi, S. A. M. (2002). Survey on Some Toxicological Problem Hazards In El-Wadi El-Gadeed "El-Dakhla"- Egypt. Ph.D. in Veterinary Medical Science, Forensic Medicine, Toxicology and Veterinary Regulations, Faculty of Veterinary Medicine, Cairo University.

[20]. Adeyemi, O., Oloyede, O.B., Oladiji, A.T. (2007). Physicochemical and microbial characteristics of Leachate contaminated ground water. Asian J.Biochem. 2(5): 343-348.

[21]. Marcovecchio, J.E., Botte, S.E., Freije, R.H. (2007). Heavy Metals, Major Metals, Trace Elements. In: Handbook of Water Analysis. L.M. Nollet, (Ed.). 2nd Edn. London: CRC Press, pp: 275.

[22]. Shrivastava K.B.L., Mishra S.P. (2011). Studies of Various Heavy Metal in Surface and Ground Water of Birsinghpur Town and its Surrounding Rural Area District Satna (M.P.). Curr. World Environ. 6, 271-274.

[23]. Hussein K. H., Osama A. A., Haddad A. E., Mohammed F. M. (2013). Estimation of some heavy metals in polluted well water and mercury accumulation in broiler. Braz. Arch. Biol. Technol. 56 (5).

[24]. Simeonove, V., Stratis, J.A., Samera, C., Zahariadis, G., Vousta, D., Anthemidis, A. (2003). Assessment of the surface water quality in Northern Greece. Water Research, 37, 4119-4124.

[25]. Moscow, S., Jothivenkatachalam, K., Subramani, P. (2011). Der Chemica Sinica 2 (2): 199-206

[26]. Bhuyan, B. (2011). Assessment of arsenic and iron contamination of groundwater in four development blocks of Lakhimpur District, Assam, India. Der Chemica Sinica 2 (4): 158-165.

[27]. Elinge, C.M., Itodo, A.U., Peni, I.J., Birnin-Yauri, U.A., Mbongo, A.N. (2011). Advances in Applied Science Research 2 (4): 279282 .

[28]. David, K.B. (2006). Evaluation of Water Quality and Nutrition for Dairy Cattle, Ph.D. Thesis, Department of Animal Science, Michigan State Univeristy, USA.

[29]. Khan R., Qureshi M.S., Mushtaq, A., Ghufranullah, Naveed, A. (2012). Effect of quality and frequency of drinking water on productivity and fertility of dairy buffaloes. Proc. Int. Workshop Dairy Sci. Park, Agric. Univ., Peshawar, Pakistan.

[30]. Rajappa, B.; Manjappa, S., Puttaiah, E.T. (2010). Monitoring of heavy metal concentration in groundwater of Hakinaka Taluk, India. Contemporary Engineering Sciences 3(4): 183-190.

[31]. Aslam, B., Javed, I., Khan, F.H., Rahman, Z. (2011). Uptake of heavy metal residues from sewerage sludge in the milk of goat and cattle during summer season. Pak. Vet. J. 31: 75.

[32]. Codex Alimentarius Commission (2003). Report of the 35th session of the Codex Committee on Food Additives and Contaminants, Arusha, Tanzania.

[33]. Hallen, I.P. (1995). Lead excretion in breast milk and transfer to suckling offspring. MSc-Thesis, Uppsala Biomedical centre, Sweden.

[34]. Okada, I.A., Sakuma, A.M., Maio, F.D., Dovidauskas, S., Zenebon, O. (1997): Evaluation of lead and cadmium levels in milk due to environmental contamination in the Paraiba Valley region of Southeastern Brazil. Journal of Public Health 31(2): 140-143.

[35]. Abdalla, M.O.M., Hassabo, A.A., Elsheik, N.A.H. (2013). Assessment of some heavy metals in waste water and milk of animals grazed around sugar cane plants in Sudan. Livestock Research for Rural Development 25(12).

[36]. Abou-Arab, A.A.K. (1997). Effect of Ras cheese manufacturing on the stability of DDT and its metabolites. J. Food Chemistry 59(1): 115-119.

[37]. Lant, A., Lomolino, G., Cagnin, M., Spettoli, P. (2006). Content and characterization of minerals in milk and in Crescenza and Squaacquerne Italian cheese by ICP-OES Food Control, 17: 229-233.

[38]. W.H.O. (2006). National water quality guidelines for domestic consumption.

[39]. W.H.O. (2008). Guidelines for drinking water quality, World Health Organization, Geneva.

[40]. Egyptian Chemical Standard (ECS) (1994). Law No.4, Protection of the Nile River and Water Stream from Pollution. Ministry of Irrigation, Cairo, Egypt.

[41]. International Dairy Federation Bulletin (IDF) (1979). Chemical Residues in milk and milk products. Document, 133

[42]. EOSQC (Egyptian Organization for Standrization and Quality Control) (1993). Maximum residues limit for heavy metals in food. Ministry of Industry. Cairo, Egypt. No. 2360/1993. p: 5.

[43]. Codex Alimentarius Commission (CAC) (2013). Working Document for Information and Use. In Discussion Related to Contaminants and Toxins in the GSCTFF. Codex Commette on Contaminants in Foods, Joint FAO/WHO Food Standarads Pogramme, Seventh Session Moscow, Russian Federation.

[44]. Goyer, R.A. (1989). Mechanism of lead and cadmium nephrotoxicity. Toxicol. Lett., $46: 153-162$

[45]. Yuzbasi, N., Sezagin E., Yildirim, M., Yildirim, Z. (2003). Survey of lead, cadmium, iron, copper and zinc in kasar cheese. Food Chem. 20: 264-269.

[46]. Azouz, M.A. (2014). Health risk of lead, cadmium and copper concentration in milk and some dairy products. Ph.D. thesis, Fac. Vet. Med. Beni Suef Univ., Egypt. 